\title{
Encyclopedia of Bondage: Re-accentuation of the Past of Slavery in Morrison's Beloved
}

\author{
Muhammad Ehsan, Zia-ur-Rehman, Muhammad Zohaib Khalil, Asima Ashraf \\ ${ }^{1} \mathrm{PhM}$ Scholar, Department of English Language and Literature, The University of Lahore, Lahore-Pakistan \\ ${ }^{2}$ Department of Literature and Linguistics Sub Campus Bahawalnagar Islamia University Bahawalpur, Pakistan \\ ${ }^{3}$ M. Phill Student, The University of Lahore, Punjab, Pakistan. \\ ${ }^{4}$ M.Phil English Literature Student, The University of Lahore Sargodha Campus, Pakistan
}

\begin{abstract}
The works of Toni Morrison to a great extent mirror the history of Afro-Americans. As a main figure of the Afro-American Renaissance, Miss Morrison makes Reaccentuation of slavery from past into present. She has made use of fiction writing as a method for remaking the past of slavery in American society. The basic thought implanted in the narrative of fiction by Morrisonis the position of black community in the white American community in the present era as well as in the past. Her writing is totally dedicated and given to black peopleand is a steady attempt to place things in the correct way and setting for them.Morrison's Beloved (1987) manages past as a storyline of the ownership of the most tangible reality of human presence as well as the most intellectual of human connections.It spotlights the dialogic inclinations of memory of the past of slavery and its inventive ability to construct and reconstruct the implication of past of slavery.
\end{abstract}

Keywords - Re-accentuation, Past of Slavery, position of blacks, significance of the past, Morrison's Beloved.

\section{REVIEW OF THE PAST OF SLAVERY AND ITS LINK TO THE CONTEMPORARY WORLD}

People of in different parts of the world have forced their fellow human into slavery over 2000 years ago.But slavery isn't just a thing of the past. A large number of women, children and men around the globe are caught in slavery, today. Millions of Africans were enslaved and shipped across the Atlantic Ocean by Americans and Europeans as a labor, particularly on manorsbetween 1500 to 1865 . The British slave trade had to an end in 1807 in the result of the resistance of enslaved Africans and the emancipationist movement.Today, a large number of women, kids and men around the world are compelled to lead lives as slaves. In present age, capitalism is the biggest enemy of poor people which leads the whole world into slavery.

\section{RE-ACCENTUATION OF THE PAST OF SLAVERY IN MORRISON'S BELOVED}

As a fourth world writer, Toni Morrison has givena new viewpoint to the perusing of the history of slavery. She has re-perused and thus rewritten the history of slavery from the angle of a dismissed race which is not yet able to come out from the appalling past of slavery and other abominable injuries. She amends the past which is a dim truthin the form of slavery, the destruction of cultural identity of the Afro-Americans and many other brutalities. Miss Morrison grabs the issues of obscure recorded personages with a specific end goal to restore their difficult past of subjection and to build them as a confident nearness in a contemporary setting.

Endeavoring to historicize the traumatic experience of slavery, Morrison dedicated Beloved "to sixty million or more", who failed to survive the "Middle Passage", embarks to offer voice to "disremembered and unaccounted for"the women and kids who left no written account. Belovedboth recalls the exploitation of ex-slaves and tells thereader how dark community is suffering of slavery of servitude like things like things as her forefathers suffered a lot.Thestudy ofBeloved uncovers her developing sympathy toward the Afro-Americanswho possess a shocking and beset past. Morrison trusts that the congruity amongst over a significant time span is extremely essential since it makes bonds, common commitments and a mutual shared account of resistance. Morrison's own particular explanation of her thought processes inreviving history for masterful look in hercritique "Rediscovering Black History,"

There is no need to be nostalgic about "the old days" because they weren't...but to recognize and rescue those qualities of resistance, excellence and integrity that were so much a part of our past and so useful to us and to the generations of blacks, now growing up. (Morrison 11) 
divulges how intensely she is related with feting the distinctivehistoric socialstandards and lineaments of resistance,excellency andreliabilitywhich were so much part of the past of black people. Pastis the primal theme of Morrison's Beloved because it is the most prestigious and irritating inheritanceof the whole black race and this community will never bury it.Characters in Morrison's Belovedare formed and deformed by their practices in slavery. So, we go back to past and forth across the view of slaverythrough Morrison's Beloved.

Marliyn Sanders Mobley in "A Different Remembering: Memory, History and Meaning in Beloved" triestoprovehowBlack history of slaverybecomes a narrative device.Morrison has written Belovedin order to repossess the past of slavery through memorizing the forefathers in a stylish way as well as in a demonstration of recorded recuperation. Obviously,Morrison makes the history of past accessible to the readersthrough textual traces in Beloved and thus lessonsthe claims to reality.Beloved is a demonstration of finding profound inside hersome association with the difficult past throughcollective memory.

In addition,Belovedis the encapsulation of the white society's wilderness andthe mental impacts of slavery. Beloved in this manner speaks to not the single child but rather the agony andsufferingof sixty million blacks who have been enslaved, tormented and died. Therefore,the rapprochement with Sethe, Paul D understands that Beloved his connection to his past of slavery.

Beloved is the vital connection which associates Africa and Americafor the oppressed women. Past for Miss Morrison is not only a record of occasions in a sequential request, but a retrieved time (Rigney 75).

"Y'all got boys," he told them. "Young boys, old boys, picky boys, stroppin boys. Now at Sweet Home, my niggers is men every one of em. Bought emthataway, raised emthataway. Men every one." (Morrison 14)

Freedom for Morrison, personally, implied that she alone controlled the use of her time. Freedom in terms of release from slavery, be that as it may, is very extraordinary. Belovedpushesitsreaders to perceive the presence of slavery in a country that would like to overlook that such a wrongdoing was ever committed. Research aims to demonstrate thatMorrisonfocuseson the fierce and desensitizing parts of slavery in order to affect the reader and thesociety in a manner that slave history should not be overlooked.
"The future was sunset; the past something to leave behind. And if it didn't stay behind, well, you might have to stomp it out. Slave life; freed life-every day was a test and a trial. Nothing could be counted on in a world where even when you were a solution you were a problem" (Morrison 256).

Beloved is a story of actual basis, an event from Afro-Americanhistorywhere exceptional significancehas been given to therevulsions andtorments of slavery has been given in order to remind the readers about past of slavery in American society as well as in the whole world. Morrisonrecreates the past of slavery and the reader should not forget what happened in Afro-American history:

Morrison's critically acclaimed novel Beloved probes the most painful part of the African American heritage, slavery, by way of what she has called "rememory" deliberatelyreconstructing what has been forgotten (Kubitschek, 1998).

\section{CONCLUSION}

The discussion of this paper scrutinizes that Beloved is satiate with history of slaveryand its unrecognized and undocumented realities. The auctorial voice says again and again "this is not a story to pass on," this is a story that gives a thought about the millions of slaves who suffered in past. Morrison's thought of her recently discovered flexibility drove her to compose Beloved, which addresses what opportunity resembled for the general population who had once in the past been slaves. Morrison arrogates she wrote Beloved as an endeavor to recuperate thestories of slavery from the slaves' point of view in order to remind Afro-Americans of their past.The paper finally concludes that Morrison's Beloveddivulges the past in order to ensure that it is not lost.

\section{REFERENCES}

[1] Archbishop Desmond Tutu, Hull, United Kingdom, 1999

[2] International Slavery Museum.Hear the untold stories of enslaved people and learn about historical and contemporary slavery. 2017

[3] Mobley, Marlyn Sanders. "A DiffernetRemebering: Memory, Perpectives, Past and Present." Eds. Henry Louis Gates Jr. and K.A. Appiah. New York: Amistad, 1993: 357-63.

[4] Morrison, Toni. "Rediscovering Black History."New York Times Magazine. 11 August 1974.

[5] Morrison, Toni. Beloved. New York: Knopf, 1987. 
[6] N. Khatana, Toni Morrison's Beloved: Rediscovering History. American International Journal of Research in Humanities, Arts and Social Sciences, ISSN (Print): 2328-3734, ISSN (Online): 2328-3696, Vol. 2(2), 2013, pp. 104-107 